\title{
Time course of bronchodilating effect of inhaled formoterol, a potent and long acting sympathomimetic
}

\author{
Eric Y Derom, Romain A Pauwels
}

\begin{abstract}
Background Most of the currently available inhaled $\beta_{2}$ agonists are short acting bronchodilators. The aim of this study was to compare the rate of onset and duration of the bronchodilating activity of formoterol and salbutamol. Methods Fourteen patients with reversible airways obstruction received placebo, $200 \mu \mathrm{g}$ salbutamol, and 12,24 , and $48 \mu \mathrm{g}$ formoterol from a metered dose inhaler, according to a double blind, randomised crossover design. Forced expiratory volume in one second $\left(\mathrm{FEV}_{1}\right)$ and specific airways conductance (sGaw) were measured over 12 hours.

Results Salbutamol and all doses of formoterol caused a significant and substantial increase in sGaw one minute after inhalation. The mean maximum increase in $\mathrm{FEV}_{1}$ was $58 \%(8 \%)$ after $200 \mu \mathrm{g}$ salbutamol compared with $63 \%$ (11\%), $62 \%$ $(10 \%)$, and $74 \%(10 \%)$ after 12,24 , and 48 $\mu g$ formoterol, respectively. The mean maximum increase in $\mathrm{FEV}_{1}$ occurred 57 (12) minutes after administration of salbutamol compared with 137 (16), 141 (21), and 161 (33) minutes after 12, 24, and $48 \mu \mathrm{g}$ formoterol respectively. The bronchodilating effect of salbutamol did not differ from placebo after six hours. In contrast, the mean increase in $F_{E V} 12$ hours after $12 \mu \mathrm{g}$ formoterol $(26 \%(8 \%)$ of baseline) significantly exceeded the change after placebo. Tremor was recorded in four patients after $48 \mu \mathrm{g}$ formoterol.
\end{abstract}

Conclusion Formoterol is a potent, fast acting bronchodilator with a long duration of action.

Inhaled $\beta_{2}$ adrenoreceptor agonists are often used as first line treatment in the management of acute and chronic asthma. However, most of the currently available inhaled $\beta_{2}$ agonists have the disadvantage of being short acting and must therefore be given three to four times a day as maintenance treatment. As their duration of action is not sufficiently long to prevent nocturnal bronchoconstriction and early morning dyspnoea, ${ }^{1}$ treatment with an inhaled $\beta_{2}$ agonist often has to be combined with an oral slow release preparation containing theophylline or $\beta_{2}$ agonist.

Formoterol is a new selective and potent $\beta_{2}$ agonist with a long duration of action when administered orally to asthmatic subjects. ${ }^{2}$ Inhalation of $12 \mu \mathrm{g}$ formoterol results in long lasting bronchodilatation and is well tolerated. The bronchodilating effect of higher doses of formoterol and its rate of onset have not been studied systematically. Our randomised, placebo controlled, crossover study was designed to investigate the onset of action, the magnitude, and the duration of the bronchodilator effect of 12,24 , and $48 \mu \mathrm{g}$ formoterol in comparison with a standard dose of inhaled salbutamol $(200 \mu \mathrm{g})$.

\section{Patients and methods}

Fourteen patients with a documented history of asthma were studied. All patients were taking inhaled $\beta_{2}$ agonist regularly; some were being treated with an inhaled corticosteroid $(n=9)$ or theophylline $(n=8)$ and one with oral prednisolone $8 \mathrm{mg}$ on alternate days (table 1 ). All patients had an initial forced expiratory volume $\left(\mathrm{FEV}_{1}\right)$ of $40 \%$ to $70 \%$ of predicted values $^{4}$ and an increase in $\mathrm{FEV}_{1}$ of at least $20 \%$ 15 minutes after inhalation of $400 \mu \mathrm{g}$ fenoterol from a metered dose inhaler. All were studied during a stable period of their disease and none had signs of a respiratory tract infection in the month preceding or during the trial. The initial $\mathrm{FEV}_{1}$ on each test day had to be within $15 \%$ of the baseline value on each study day. Informed consent was given by the patients and the study was approved by the ethical committee of the University Hospital of Ghent.

\section{LUNG FUNCTION MEASUREMENTS}

$\mathrm{FEV}_{1}$ was measured with a water sealed spirometer (Expirograph Godart) and taken as the highest of three consecutive measurements. Specific airways conductance (sGaw) was calculated from airways resistance and thoracic gas volume, measured with a constant volume body plethysmograph (Jaeger, Würzburg, Germany); each value was the mean of eight consecutive measurements.

\section{DESIGN OF THE STUDY}

The bronchodilator activity of placebo, $200 \mu \mathrm{g}$ salbutamol, and 12,24 , and $48 \mu \mathrm{g}$ formoterol was investigated on five non-consecutive days (at least two days apart, and at most seven days). The study was double blind, randomised and crossover. All inhalers looked identical and their contents did not differ in taste or smell. The patients were instructed carefully on how 


\begin{tabular}{|c|c|c|c|c|c|c|}
\hline \multirow[b]{2}{*}{ Case No } & \multirow[b]{2}{*}{ Sex } & \multirow[b]{2}{*}{ Age (years) } & \multicolumn{2}{|l|}{$F E V_{1}$} & \multirow[b]{2}{*}{ Smoking history } & \multirow[b]{2}{*}{$\begin{array}{l}\text { Current } \\
\text { asthma } \\
\text { treatment }\end{array}$} \\
\hline & & & Baseline (1) & $\begin{array}{l}\text { Reversibility } \\
\text { (\% change } \\
\text { from baseline) }\end{array}$ & & \\
\hline 1 & $\mathbf{M}$ & 30 & 3.01 & 35 & Non-smoker & $\mathrm{Bi}, \mathrm{Si}$ \\
\hline 2 & F & 58 & 1.58 & 44 & Non-smoker & $\mathrm{Bi}, \mathrm{Si}, \mathrm{T}$ \\
\hline 3 & $\mathbf{M}$ & 40 & $1 \cdot 29$ & 55 & Non-smoker & $\mathrm{Bi}, \mathrm{Si}, \mathrm{T}$ \\
\hline 4 & $\mathbf{M}$ & 23 & 2.90 & 66 & Non-smoker & $\mathrm{Bi}$ \\
\hline 5 & $\mathbf{M}$ & 18 & $3 \cdot 29$ & 30 & Non-smoker & $\mathrm{Bi}, \mathrm{Si}, \mathrm{T}$ \\
\hline 6 & $\mathbf{M}$ & 21 & 1.99 & 37 & Ex-smoker & $\mathrm{Bi}, \mathrm{Si}$ \\
\hline 7 & F & 39 & 2.55 & 26 & Non-smoker & $\mathrm{Bi}, \mathrm{Si}, \mathrm{T}$ \\
\hline 8 & $\mathbf{M}$ & 22 & 3.49 & 35 & Non-smoker & $\mathrm{Bi}$ \\
\hline 9 & $\mathbf{M}$ & 40 & $1 \cdot 24$ & 96 & Non-smoker & $\mathrm{Bi}, \mathrm{T}$ \\
\hline 10 & $\mathbf{M}$ & 50 & $2 \cdot 26$ & 23 & Smoker & $\mathbf{B i}, \mathbf{S i}$ \\
\hline 11 & $\mathbf{M}$ & 52 & $1 \cdot 29$ & 70 & Ex-smoker & $\mathrm{Bi}, \mathrm{T}$ \\
\hline 12 & $\mathbf{M}$ & 57 & 1.02 & 100 & Ex-smoker & $\mathrm{Bi}, \mathrm{Si}, \mathrm{T}$, So \\
\hline 13 & $\mathbf{M}$ & 46 & $1 \cdot 72$ & 20 & Smoker & $\mathrm{Bi}, \mathrm{Si}, \mathrm{T}$ \\
\hline 14 & $\mathbf{M}$ & 47 & $2 \cdot 36$ & 37 & Ex-smoker & $\mathrm{Bi}$ \\
\hline
\end{tabular}

$\mathrm{Bi}=$ inhaled $\beta_{2}$ agonist, $\mathrm{Si}=$ inhaled steroids, $\mathrm{So}=$ oral steroids, $\mathrm{T}=$ oral theophylline.

to take two inhalations from the metered dose inhaler.

Patients arrived at the laboratory at 7.45 am on the five study days. Inhaled $\beta_{2}$ agonists and anticholinergic drugs were withdrawn 12 hours before the start of the trial, and oral $\beta_{2}$ agonists, long acting theophylline preparations, caffeinated drinks, and diuretics 24 hours before. Oral and inhaled corticosteroids were continued at constant dose. Serum theophylline concentrations were determined on each study day.

After 30 minutes baseline measurements of heart rate, blood pressure, sGaw, and $\mathrm{FEV}_{1}$ were performed. Since deep inspirations are known to cause bronchoconstriction in asthmatic subjects, 5 sGaw was always measured first. Patients were then asked to inhale two puffs of the test drug. Heart rate and blood pressure were measured $10,30,60$, and 120 minutes after inhalation. sGaw was measured $1,3,5$, and 10 minutes after inhalation and sGaw and $F_{E V} 15,30,60,120,180,240,360$, 480,600 , and 720 minutes after inhalation.

Toleration of the trial drug was assessed during the study day by questioning the patient about potential adverse effects. All patients were provided with rescue treatment (terbutaline metered dose aerosol), which they were allowed to use 12 hours before the study and throughout the examination day if necessary. Each extra inhalation was reported to the physician supervising the trial.

\section{ANALYSIS}

All data obtained after rescue treatment was used were discarded and replaced by the data obtained immediately before the extra inhalation.

The maximum increases from baseline $\mathrm{FEV}_{1}$ and sGaw with the different drugs were compared and the $F E V_{1}$ and sGaw at 12 hours were assessed and compared by analysis of variance for treatment and time. The mean times after inhalation at which $\mathrm{FEV}_{1}$ and $\mathrm{sGaw}$ were maximal were also compared.

To investigate the rate of onset of the bronchodilating effect of the different treatments after 1, 3, and 5 minutes, the absolute increase in $\mathrm{sGaw}$ and the increase in $\mathrm{sGaw}$ relative to the peak response in sGaw were calculated.

Maximal changes and mean changes at fixed time points in $F E V_{1}$ and sGaw were expressed as the mean (SE) percentage changes from the baseline value. Time to maximal bronchodilatation was also expressed as mean (SE).

\section{Results}

There was no significant difference in mean baseline $\mathrm{FEV}_{1}$ or sGaw on the five study days (table 2). Serum theophylline concentrations at the start of each test day were below $4 \mathrm{mg} / \mathrm{l}$ in all patients.

\section{RESCUE TREATMENT}

On a total of 70 examination days rescue treatment was needed on only three occasions. Two patients receiving placebo used two puffs of terbutaline 30 and 240 minutes after the beginning of the trial. At these time points $\mathrm{FEV}_{1}$ had decreased by $28 \%$ from baseline values in both patients. The third patient initially responded well to $48 \mu \mathrm{g}$ formoterol, but he then developed a progressive decrease in $\mathrm{FEV}_{1}(-17 \%$ of baseline values after 10 hours) and chose to inhale two puffs of terbutaline.

\section{TIME COURSE OF BRONCHODILATING EFFECT}

All doses of formoterol caused a greater increase in $\mathrm{FEV}_{1}$ than placebo or salbutamol (both $\mathrm{p}<0.001$ ) (figures 1 and 2). Inhalation of 12 and $24 \mu \mathrm{g}$ formoterol resulted in an almost identical increase in $\mathrm{FEV}_{1}$ over 12 hours; $48 \mu \mathrm{g}$ formoterol caused a greater response than 12 and $24 \mu \mathrm{g}$ (both $\mathrm{p}<0.001$ ). The formoterol induced increase in sGaw was dose dependent.

\section{MAXIMUM RESPONSE}

Maximum changes in $\mathrm{FEV}_{1}$ and sGaw are given both in absolute (table 2 ) and in relative (table 3) terms. The maximum increase in $\mathrm{FEV}_{1}$ after $200 \mu \mathrm{g}$ salbutamol was $52 \%(8 \%)$ of baseline values, which was more than the maximum change observed on the placebo day $(\mathrm{p}<0.01)$. The maximum increase in $\mathrm{FEV}_{1}$ 
Table 2 Mean (SE) baseline and maximum values of FEV, and sGaw with different treatments

\begin{tabular}{|c|c|c|c|c|c|}
\hline & \multirow[b]{2}{*}{ Placebo } & \multirow{2}{*}{$\begin{array}{l}\text { Salbutamol } \\
200 \mu \mathrm{g}\end{array}$} & \multicolumn{3}{|l|}{ Formoterol ( $\mu \mathrm{g})$} \\
\hline & & & 12 & 24 & 48 \\
\hline \multicolumn{6}{|c|}{$F E V_{1}(l)$} \\
\hline $\begin{array}{l}\text { Baseline } \\
\text { Maximum }\end{array}$ & $\begin{array}{ll}2.00 & (0.20) \\
2.36 & (0.22)\end{array}$ & $\begin{array}{ll}2.11 & (0.24) \\
3.03 & (0.26)\end{array}$ & $\begin{array}{ll}1.98 & (0.24) \\
3.05 & (0.29)\end{array}$ & $\begin{array}{ll}2.05 & (0.24) \\
3.16 & (0.28)\end{array}$ & $\begin{array}{ll}1.96 & (0.20) \\
3.22 & (0.27)\end{array}$ \\
\hline \multicolumn{6}{|c|}{ sGaw ( $\left.\mathrm{cm} \mathrm{H}_{2} \mathrm{O} . \mathrm{s}\right)$} \\
\hline $\begin{array}{l}\text { Baseline } \\
\text { Maximum }\end{array}$ & $\begin{array}{l}0.031(0.003) \\
0.066(0.008\end{array}$ & $\begin{array}{l}0.041(0.005) \\
0.130(0.016)\end{array}$ & $\begin{array}{l}0.041(0.006) \\
0.133(0.018)\end{array}$ & $\begin{array}{l}0.038(0.006) \\
0.151(0.022)\end{array}$ & $\begin{array}{l}0.035(0.003) \\
0.167(0.021)\end{array}$ \\
\hline
\end{tabular}

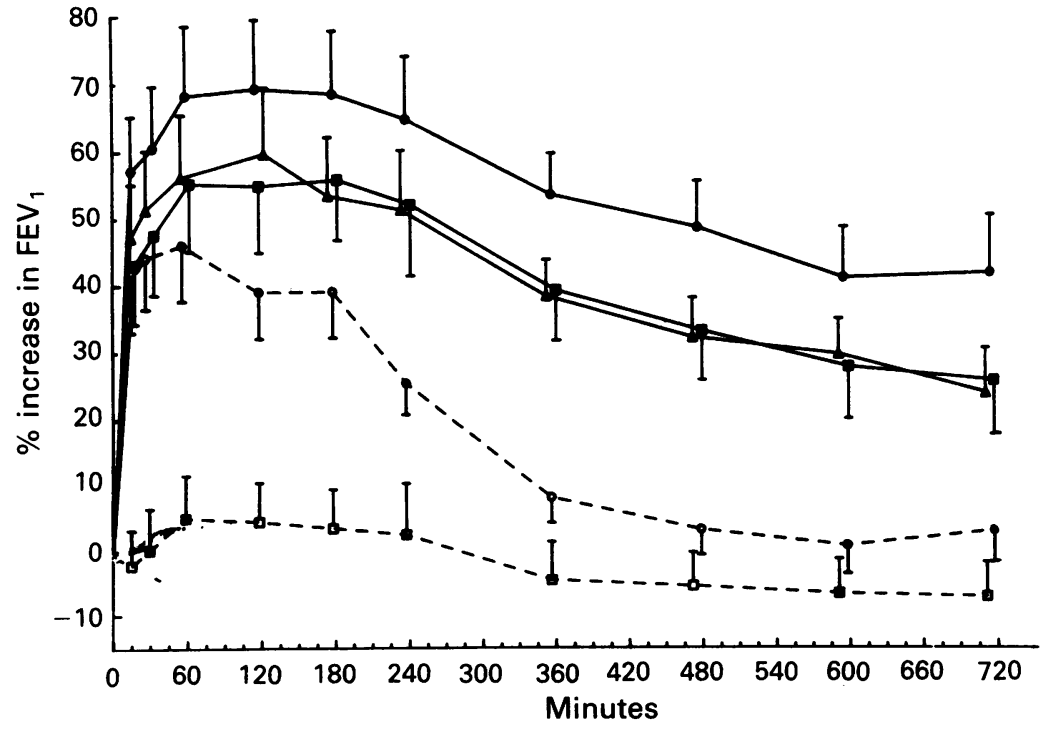

Figure 1 Time course of change in FEV (mean (SE) in 14 patients) after inhalation of placebo ( $\square-(--\square)$, salbutamol ( $O--O), 12 \mu \mathrm{g}$ formoterol ( $\square-\square$ ), $24 \mu \mathrm{g}$ formoterol ( $\triangle-\Lambda$ ), and $48 \mu \mathrm{g}$ formoterol (

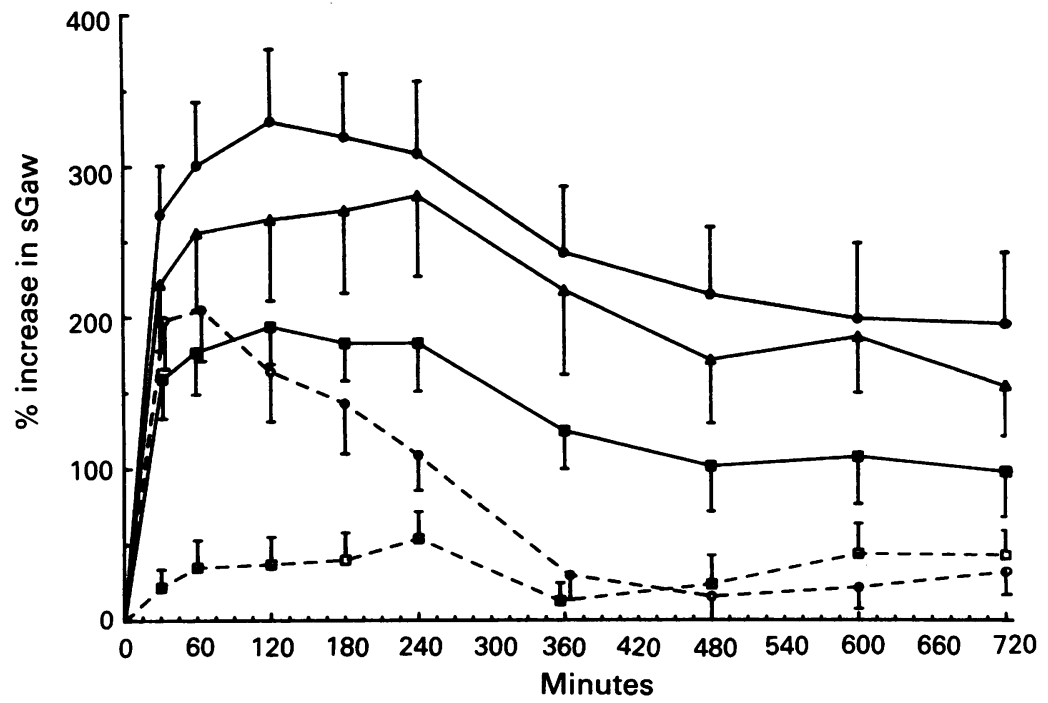

Figure 2 Time course of change in sGaw after inhalation of placebo, salbutamol, and formoterol (same key as figure 1).

after 12 and $24 \mu \mathrm{g}$ formoterol was not significantly different from that after salbutamol. The maximum increase in $\mathrm{FEV}_{1}$ after $48 \mu \mathrm{g}$ formoterol was greater than the increase after salbutamol $(p<0.01$ ) or $12 \mu \mathrm{g}$ formoterol $(p<0.05)$. The maximum increase in sGaw after salbutamol was similar to that obtained after $12 \mu \mathrm{g}$ formoterol. Maximum sGaw achieved with 24 and $48 \mu \mathrm{g}$ formoterol was greater than that with salbutamol $(p<0.01)$.
DURATION

At 12 hours the mean increase in $\mathrm{FEV}_{1}$ and sGaw (figures 1 and 2 and table 3 ) produced by all doses of formoterol was greater than the effect observed after placebo or salbutamol (all $\mathrm{p}<0.05)$.

\section{TIME OF MAXIMUM RESPONSE}

The mean time of maximum increase in FEV for salbutamol was 57 (SE 12) minutes after inhalation and more than 120 minutes for all doses of formoterol $(p<0.01)$.

\section{RATE OF ONSET OF ACTION}

sGaw increased at 1,3 , and 5 minutes after inhalation of salbutamol and all doses of formoterol (figure 3). When the bronchodilating effect was expressed as a percentage of the maximum response, the rate of onset after salbutamol was more rapid than after formoterol. One minute after inhalation of salbutamol sGaw was $63 \%$ (6\%) of its maximum response compared with $47 \%(7 \%)$ of its maximum response after $24 \mu \mathrm{g}$ formoterol $(p<0.01)$. sGaw further increased at three and five minutes after each active treatment.

\section{BLOOD PRESSURE AND HEART RATE}

Changes in systolic or diastolic blood pressure were small and not significant. The maximum increase in heart rate did not exceed 5 beats/ min and differences between treatments were not significant (paired $t$ test).

\section{SIDE EFFECTS}

Treatments were generally well tolerated. Only after inhalation of $48 \mu \mathrm{g}$ formoterol was a mild but not disturbing tremor noted by four of the 14 patients. Headache was reported by one patient after formoterol, salbutamol, and placebo.

\section{Discussion}

Our results show clearly that $12 \mu \mathrm{g}$ inhaled formoterol produces a maximal bronchodilating effect that equals the bronchodilator effect of $200 \mu \mathrm{g}$ of inhaled salbutamol. At this equipotent dose inhaled formoterol results in a significantly longer duration of action. Indeed, 12 hours after the inhalation of $12 \mu \mathrm{g}$ formoterol a significant effect on $\mathrm{FEV}_{1}$ and sGaw was apparent. The rate of onset of the bronchodilating action of formoterol is roughly similar to that of salbutamol (figure 3). When our data were expressed as a percentage of the maximum response or as time at which the maximum response was reached the rate of 
Table 3 Maximum increase in FEV, and sGaw and change at 12 hours with different treatments. Values are means (SE) as percentages of baseline values

\begin{tabular}{|c|c|c|c|c|c|}
\hline & \multirow[b]{2}{*}{ Placebo } & \multirow{2}{*}{$\begin{array}{l}\text { Salbutamol } \\
200 \mu \mathrm{g}\end{array}$} & \multicolumn{3}{|c|}{ Formoterol ( $\mu \mathrm{g})$} \\
\hline & & & 12 & 24 & 48 \\
\hline \multicolumn{6}{|c|}{$F E V_{1}(l)$} \\
\hline $\begin{array}{l}\text { Maximum increase } \\
\text { Change at } 12 \text { hours }\end{array}$ & $\begin{array}{r}13(7) \\
-6 \quad(5)\end{array}$ & $\begin{aligned} 52 & (8) \\
4 & (5)\end{aligned}$ & $\begin{array}{l}63(11) \\
26(8)\end{array}$ & $\begin{array}{l}62(10) \\
24(7)\end{array}$ & $\begin{array}{lr}74 & (10) \\
42 & (9)\end{array}$ \\
\hline \multicolumn{6}{|c|}{ sGaw } \\
\hline $\begin{array}{l}\text { Maximum increase } \\
\text { Change at } 12 \text { hours }\end{array}$ & $\begin{array}{l}83(2) \\
43(16)\end{array}$ & $\begin{array}{r}236(32) \\
32(15)\end{array}$ & $\begin{aligned} 231 & (27) \\
98 & (30)\end{aligned}$ & $\begin{array}{l}330(56) \\
154(33)\end{array}$ & $\begin{array}{l}366(49) \\
195(47)\end{array}$ \\
\hline
\end{tabular}

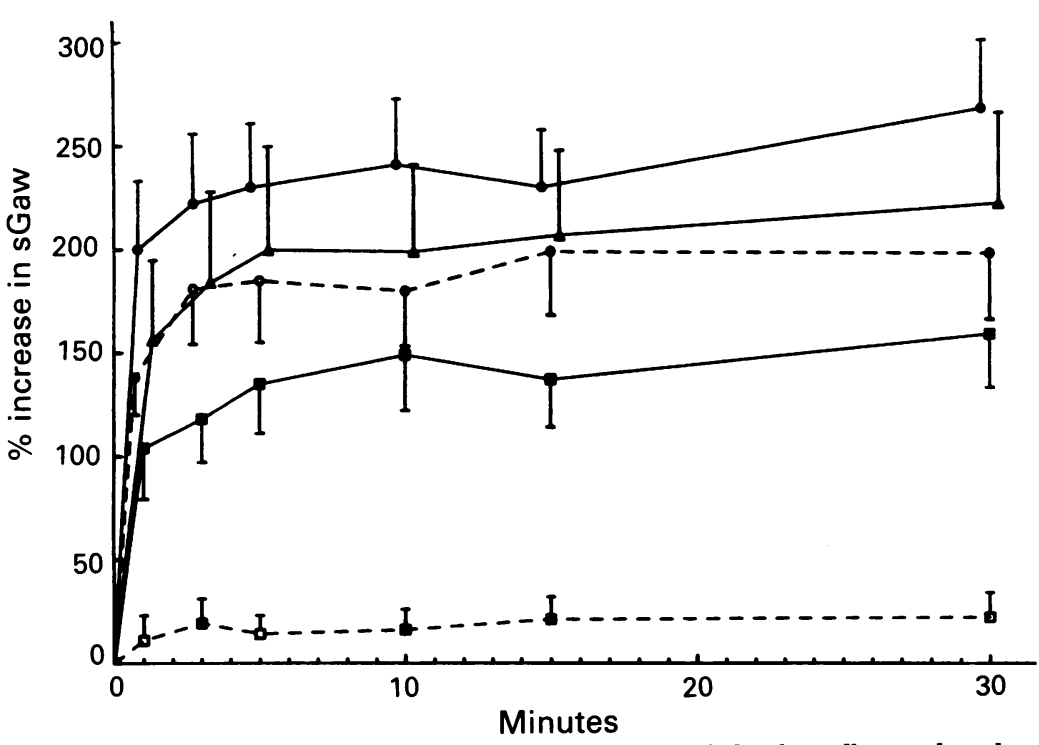

Figure 3 Time course of change in sGaw after inhalation of placebo, salbutamol, and formoterol for the first 30 minutes (same key as figure 1).

onset of action of salbutamol was faster than that of formoterol.

Our study does not allow a final conclusion to be made about the relative potency of salbutamol and formoterol. To do this the dose of inhaled formoterol that is equivalent to the dose of inhaled salbutamol would have to be determined systematically in each patient as differences in duration of action may be expected when non-equivalent doses of $\beta_{2}$ agonists are compared. As a consequence, only a doseresponse curve for both drugs allows a proper comparison of the potency and duration of action of the two drugs.

The longer duration of action observed with 24 and $48 \mu \mathrm{g}$ formoterol was probably partly due to a greater relative dose of $\beta_{2}$ agonist. Indeed, at these doses the maximum increase in FEV , and in sGaw clearly exceeded the maximum increase after $200 \mu \mathrm{g}$ salbutamol. This explanation, however, does not seem to be valid for $12 \mu \mathrm{g}$ formoterol, whose maximum effect on $\mathrm{FEV}_{1}$ was only slightly greater than the increase produced by $200 \mu \mathrm{g}$ salbutamol. The increase in sGaw after $12 \mu \mathrm{g}$ formoterol did not exceed the increase after $200 \mu \mathrm{g}$ salbutamol. Thus $200 \mu \mathrm{g}$ salbutamol and $12 \mu \mathrm{g}$ formoterol probably differ only slightly in their bronchodilating potency. This is in line with a recent study in which cumulatively increasing doses of salbutamol and formoterol were administered to asthmatic subjects. ${ }^{6}$ Thus the longer duration of action of $12 \mu \mathrm{g}$ formoterol may be ascribed to long lasting $\beta_{2}$ stimulating activity at the level of bronchial smooth muscle.
The mechanism, however, remains to be elucidated.

We observed a significant dose-response relation in the bronchodilating effect of formoterol, that of the $48 \mu \mathrm{g}$ dose being clearly superior to that of $12 \mu \mathrm{g}$. Measurement of change in $\mathrm{FEV}_{1}$ could not distinguish between the 12 and the $24 \mu \mathrm{g}$ dose, though the increase in sGaw was significantly lower for the two lowest doses of formoterol.

Formoterol was well tolerated. No cardiovascular effects were observed, and only after the $48 \mu \mathrm{g}$ dose of formoterol was a mild, but not disturbing, tremor reported by four of the 14 patients.

Our observations may have important clinical implications in the treatment of asthmatic patients. Firstly, the long acting bronchodilating effect of formoterol should enable the frequency of regular inhalation of sympathomimetic agents to be reduced from four to two times a day, thus increasing therapeutic compliance. Secondly, our study is the first to provide convincing evidence that formoterol, even at higher than recommended doses, presents a slower rate of onset of action than a standard dose of salbutamol. The clinical relevance of this finding should be evaluated by comparing salbutamol and formoterol in a dose-response study in the treatment of acute asthma.

In conclusion, we found that inhaled formoterol is a potent bronchodilator that produces a rapid and long lasting bronchodilatation in asthmatic patients and has few side effects. Further investigations with inhaled formoterol at 12 and $24 \mu \mathrm{g}$ twice daily are required to assess its clinical value over a longer period of time.

We thank Mrs V Collart and Mr F De Vriendt for their expert technical help, and Mrs C Vandeven and Mrs H Vervaet for the preparation of the manuscript.

This study was supported by a grant from Ciba-Geigy, Basle, Switzerland.

1 Joad JP, Ahrens RC, Lindgren SD, Weinberger MM Relative efficacy of maintenance therapy with theophylline, inhaled albuterol, and the combination for chronic asthma. J Allergy Clin Immunol 1987;79:78-85.

2 Nakajima S, Oishi M, Shida T, Iwakura M, Makino S, Kihara N, et al. Dose-response evaluation of bronchodilation effect of formoterol (BD $40 \mathrm{~A}$ ) in single doses in bronchial asthma. Journal of Medical and Pharmacological Science (Japan) 1983;10:571-82.

3 Maesen FPV, Smeets JJ, Gubbelmans HLL, Zweers PGMA. Bronchodilator effect of inhaled formoterol vs salbutamol over 12 hours. Chest 1990;97:590-4.

4 Quanjer PH. Standardized lung function testing. Bull Eur Physiopathol Respir 1983;19(suppl 5):1-95.

5 Gayrard P, Orehek J, Grimaud C, Charpin J. Bronchoconstrictor effects of a deep inspiration in patients with asthma. Am Rev Respir Dis 1975;111:433-9.

6 Löfdahl CG, Svedmyr N. Formoterol fumarate, a new $\beta_{2}$ adrenoreceptor agonist. Allergy 1989;44:264-71. 